\title{
Effect of Glass Fiber on Compressive, Flexural and Spliting Strength of Reactive Powder Concrete
}

\author{
Widodo Kushartomo ${ }^{1, *}$, Richard Ivan $^{2}$ \\ ${ }^{1,2}$ Department of Civil Engineering, Tarumanagara University, Jakarta, Indonesia
}

\begin{abstract}
Reactive Powder Concrete (RPC) is a new technology in high strength concrete industry. Steel fibers are usually used as reinforcements in RPC mixture. In this research, steel fibers in RPC mixture are replaced by fiberglass. The volume of fibers used are $1 \%, 1.5 \%$, and $2 \%$. Curing process by steam curing in 12 hours. The concrete was tested after 28 days including compressive test, split tensile test, and flexural test. The result shown that optimal value of fiberglass added to mixture was $2 \%$ from total volume with compressive strength value at $127.38 \mathrm{MPa}$, split tensile strength at $9.844 \mathrm{MPa}$, and flexural strength at $10.36 \mathrm{MPa}$. Density of fiberglass reinforced concrete at optimum volume is $2224.3029 \mathrm{~kg} / \mathrm{m}^{3}$ it was lower than steel fibers reinforced concrete at optimum volume which has density of $2310.385 \mathrm{~kg} / \mathrm{m}^{3}$.
\end{abstract}

\section{Introduction}

The need of high strength concretes is a must in construction industries nowadays. Reactive Powder Concrete (RPC) is one of the high strength concrete technology. RPC was first developed and produced by P. Richard and M. Cheyrezy in the early 1990s as researchers in a laboratory in France, known as Bouygues Laboratory.

RPC is a composite material of cement with high strength and ductility. RPC is a concrete without coarse aggregate. Its microstructure is optimized by the appropriate particle size distributionof the materials contained in a concrete mixture to increase the density of this concrete. RPC consists of very fine aggregates (such as sand, cement, and silica fume), steel fibers, and superplasticizer. The range of the compressive strength of RPC is from 200 to 800 $\mathrm{MPa}$. A high strength could make RPC fragile.Therefore, steel fibers are usually added into the RPC mixture to increase its ductility. The addition of fibers into a concrete can increase its strength and toughness. The direction of the fibers, the length of the fibers, and the tensile strength of the fibers affect concrete strength and toughness [1]. The critical length is the minimum length of the fiber required to retain stress or tension equal to the fiber's strength. The use of shorter or longer fiber beyond its critical length will cause the non-optimum strength and capacity of the fiber to retain stress or tension [1].

*corresponding author: widodo@untar.ac.id 
In this research, steel fibers in a RPC mixture will be replaced with fiberglass. Fiberglass is polymer fibers strengthened by glass fibers. Fiberglass is a light and strong material usually used for gliders, boat manufactures, water tanks, cars, etc. Fiberglass was chosen because this material is light but strong against tensile and tension. The tensile strength of fiberglass is higher compared to steel fibers [1-3].

The research of fiberglass use as a reinforcement of a concrete was first conducted in Russia in 1940s and was then introduced to the world's building industry in the early 1970s in the United Kingdom. Glass Fiber Reinforced Concrete(GFRC) is a fiberglass mixture with cement matrix. This mixture maintains the physical and chemical identity of the fiber and even the cement matrix synergistically and reaches a combination of properties which could never been achieved individually. The fibers retain loads while the cement matrix maintains the location of the fiber reinforcement and also protects the fibers from damage caused by the surrounding environment [4-7].

Flexural strength of the fibrous concrete is affected by the volume and ratio aspect of the fibers in a concrete mixture [1]. Because of these factors, we had been conducted experiment in this research by using a different value of fraction of the fiber volume. The length and diameter of steel fibers used were from 11.0 to $13.0 \mathrm{~mm}$ and from 0,12 to $0,13 \mathrm{~mm}$ respectively. The tensile strength of the fibers were $1200 \mathrm{MPa}$. They were produced by Hebei Yusen Steel Wire Mesh Co.,Ltd. The fiberglass used was produced by PT. Justus Kimia raya conducting continuous roving with a tensile strength of $2400 \mathrm{MPa}$.

This research was intended to know the difference of compressive, splitting, and the flexural strength of a RPC with steel fibers and fiberglass mixtures. Furthermore, this research was also intended to identify the fraction of the optimum volume of the addition of each materials into the RPC mixture.

\section{Research Methods}

The materials used in this research are PCC cement, sand with a maximum grain size of 0.6 $\mathrm{mm}$, water, silica fume, superplasticizer viscocrete-10, AR-Glass as fiberglass, and steel fibers. The mix designused are as the ones below:

Table 1.Typical RPC composition

\begin{tabular}{|c|c|}
\hline Material & Ratio by weight \\
\hline Cement & 1.00 \\
\hline Silica fume & 0.25 \\
\hline Sand & 1.50 \\
\hline Super plasticizer & 0.03 \\
\hline Water & 0.20 \\
\hline Fiber fraction volumes (\%) & 1,$0 ; 1,5 ; 2$ \\
\hline
\end{tabular}

Before making the specimens, a test was done for fine aggregates based on standard examinations. There were 10 cylindrical specimens $(7.5 \mathrm{~cm} \times 15 \mathrm{~cm})$ and 2 beams $(10 \mathrm{~cm} \times 10$ $\mathrm{cm} \times 40 \mathrm{~cm}$ ) prepared for each kind of fiber and volume fraction. The concrete treatment technique used was the steam method. The examination was done after the concrete has reached 28 days. 
The compressive strength examination was done on 5 cylindrical specimens based on ASTM C39 [8]. The splitting strength examination was conducted on 5 cylindrical specimens based on the splitting strength value $\left(\mathrm{F}_{\mathrm{ct}}\right)$ [9], and The flexural strength examination was carried out on the beam specimens based on the flexural strength value $\left(\mathrm{F}_{\mathrm{r}}\right)[10]$ :

\section{Results And Discussions}

The addition of fibers into the RPC mixture can increase its strength because the addition of fibers prevent cracks propagation caused by loadings or forces [11,12]. Results of the examination are shown in Table 2. The process of the examination of compressive, splitting, and flexural strength are shown in Figure 1.

The addition of fiberglass and steel fibers in a concrete increases compressive, splitting, and flexural strength of the concrete.The increases those concrette strengths due to addition steel fibers were greater compared to the addition of fiberglass.

We can conclude that the optimum value for the addition of fibers were different between steel fibers and fiberglass. The optimum value for the addition of steel fibers with the volume fraction of $1.5 \%$ was $95.89 \mathrm{MPa}$ for its compressive strength are show in Figure 2, $13.11 \mathrm{MPa}$ for its flexural strength are shown in Figure 3 and $12.414 \mathrm{MPa}$ for its splitting strength are shown in Figure 4. The optimum value for fiberglass additoin with the volume fraction of $2 \%$ was 90.380 MPa for its compressive strength, 11.020 MPa for its splitting strength, and 10.363 $\mathrm{MPa}$ for its flexural strength.

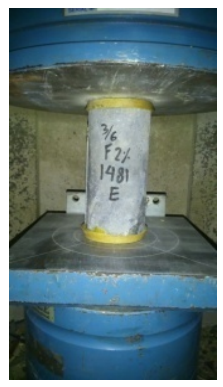

(a)

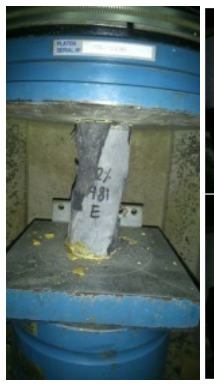

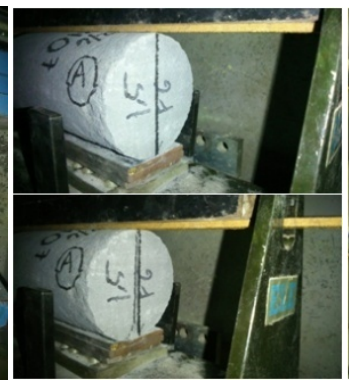

(b)

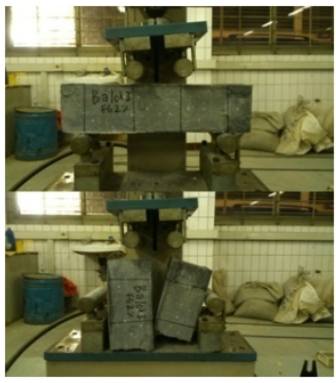

(c)

Figure 1. (a) Compressive Strength Examination, (b) Splitting Strength Examination, (c)Flexural Strength Examination 


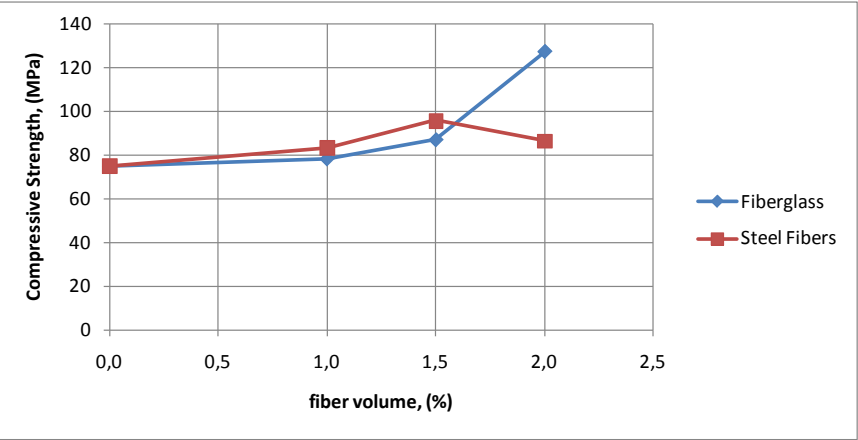

Figure 2. Effect of fibers volume additions on compressive strength of reactive powder concrete

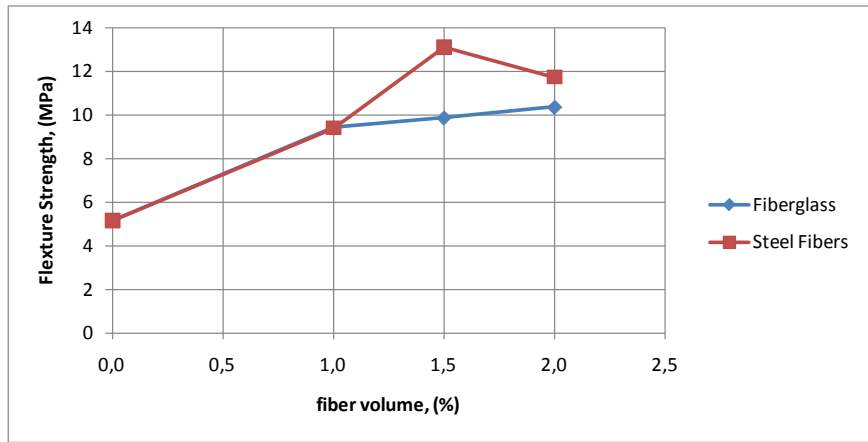

Figure 3. Effect of fibers volume additions on flexture strength of reactive powder concrete.

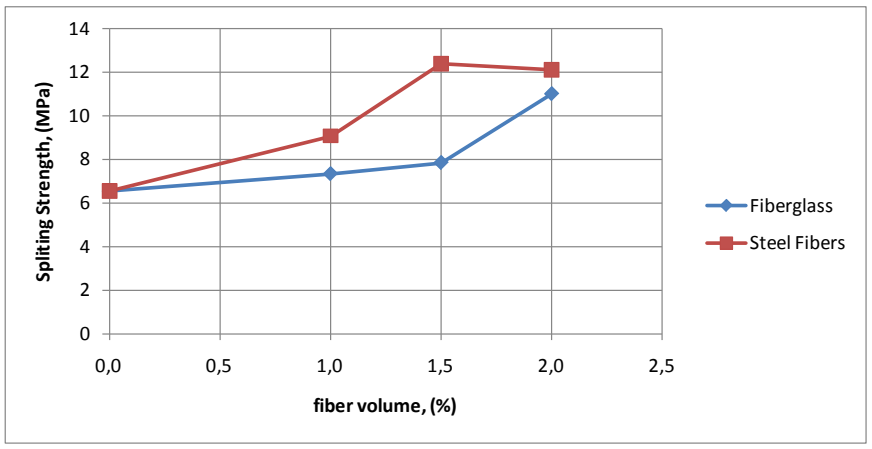

Figure 4. Effect of fibers volume additions on spliting strength of reactive powder concrete. 


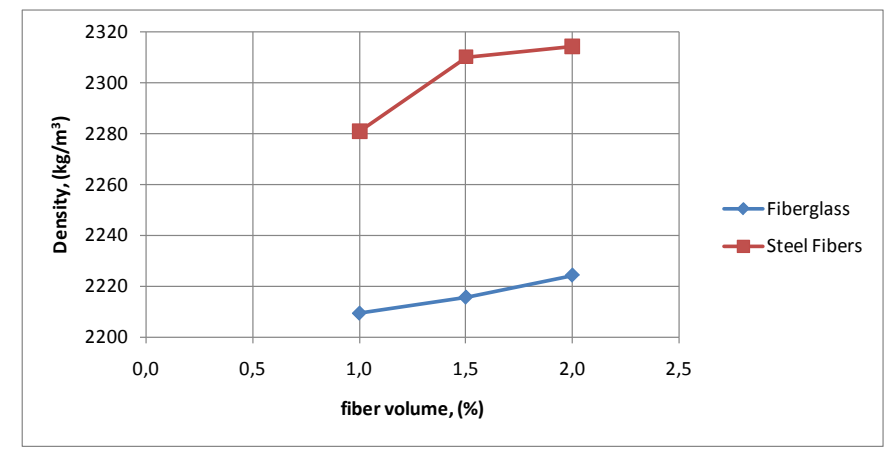

Figure 5. Effect of fibers volume additions on density of reactive powder concrete.

Based on the results of the examination are shown in Figure 2, the changes in the strength of the concrete with steel fibers reinforcement increased after the addition of $1 \%$ until the peak which is $1.5 \%$ and then decreased when it was added until $2 \%$. The changes in the strength of the concrete with fiberglass reinforcement continuously increased from the addition of $1 \%$ until $2 \%$.

The increase of the flexural strength value on Figure 3 and splitting strength value on Figure 4 of the concrete due to the addition of steel fibers was in general higher than the concrete added with fiberglass. However, the overall average density of the concretes for each of the volume fractions with fiberglass is smaller than the one with steel fibers. These results are shown in Figure 5. Moreover, the difference of the mechanical properties value of the concrete, with the addition of fiberglass at the value of $2 \%$, with a lower density, was very small compared to value of mechanical properties the addition of steel fibers at the optimum value which is $1.5 \%$.

The value of flexural and splitting strength of the concrete with the addition of fiberglass was lower compared to the ones with the addition of steel fibers. This was because the ratio aspects which wre too excessive on concretes with fiberglass, where the length of the fiberglass used was between $30-40 \mathrm{~mm}$ compared to the diameters of the fibers which is relatively small, about $14 \mu \mathrm{m}$ per filament. Mean while the ratio aspects on concretes with steel fibers were too large because the length of the fibers wass about $11,0-13,0 \mathrm{~mm}$ with a diameter about $0,12-0,13$ $\mathrm{mm}$. The addition of fiberglass into the RPC mixture could increase the durability of the concrete against cracks (crack resistance) caused by heat of hydration, creep, and shrinkage.

\section{Conclusions}

Based on the results of this research, the followings could be concluded:

- The addition of steel fibers and fiberglass into a RPC increases the mechanical property of the concrete.

- The optimum value of the fiberglass added into the RPC was when the volume fraction is $2 \%$.

- The optimum value of steel fibers added into the RPC wass when the volume fraction is $1.5 \%$.

- When the value of volume fractionwas optimum, the flexural and splitting strength of the RPC with steel fibers reinforcement was higher and stronger than the RPC with fiberglass reinforcement. However, the compressive strength of the RPC with fiberglass reinforcement is higher and stronger compared to the RPC with steel fibers reinforcement.

- The density of the RPC with fiberglass reinforcement is overall smaller compared to the RPC with steel fibers reinforcement. 
- The use of fiberglass and steel fibers on RPC could prevent cracks caused by heat by hydration, creep, and shrinkage.

\section{References}

1. A. Bentur, S. Mindess, , Fibre reinforced cementitious composites (Elsevier Sience Publishers LTD, England, 1990)

2. A. Sukumar,E.John,International Journal of Innovative Reasearch in Advanced Engineering,Fiber addition and its effect on concrete strength, 1, 144-149(2014)

3. Q.Zao, J.Yu, G.Geng, J.Jiang, X . Liu, Construction and Building Materials Journal, Effect of fiber types on creep behavior of concrete, 105, 416-422(2016)

4. S. Kakooei, H. Md Akil, M. Jamshidi, J. Rouhi,Construction and Building Materials Journal, The effects of polypropylene fibers on the properties of reinforced concrete structures, 27, 73-77(2012)

5. S. Alsadey, M. Salem, American Journal of Engineering Research,Influence of polypropylene fiber on strength of concrete, 5, pp 223-226(2016).

6. P.Zhang, Q. Li, Composites Part B: Engineering Journal,Effect of polypropylene fiber on durability of concrete composite containing fly ash and silica fume,45, 1587-1594(2013).

7. G.M. SadiqulIslam, S. DasGupta. International Journal of Sustainable Built Environment, Evaluating plastic shrinkage and permeability of polypropylene fiber reinforced concrete, $\mathbf{5}$, 345-354(2016).

8. ASTM International, Standard test method for splitting tensile strength of cylindrical concrete specimens(ASTM C496, 2002).

9. ASTM International, Standard test method for flexural strength of concrete (Using Simple Beam with Third-Point Loading (ASTM C78, 2002)

10. ASTM International, Standard test method for compressive strength of cylindrical concrete specimens(ASTM C39, 2002).

11. M. A. Mohamed, M. A.Moh, N. W. Akasha, I. Y. I. Elgady, experimental study on effects of fiberglass and fiber waste in concrete mixes, International Journal of Engineering Science \& Research Technology, 3, 485-493, (2016).

12. B. Graybeal A., F. Baby, Development of Direct Tension Test Method for Ultra-HighPerformance Fiber-Reinforced Concrete, ACI Materials Journal, 110, 177-186, (2013). 